\title{
On the issue of bankruptcy of a peasant (farm) economy
}

\author{
Oksana Morozova ${ }^{1 *}$ and Olga Kichalyuk ${ }^{1}$ \\ ${ }^{1}$ Institute of Service and Entrepreneurship (branch) of DSTU in SHAKHTY, 147, Shevchenko str., \\ 346500, Shakhty, Russia.
}

\begin{abstract}
The article examines the issues of legal regulation of the bankruptcy of a peasant (farm) economy in Russia. The authors analyze the legislation that determines the legal basis for bankruptcy, especially the bankruptcy of a peasant (farm) economy, methods of state support for this entity as well as some shortcomings in the legal regulation of bankruptcy of peasant farms as one of the areas of the agro-industrial complex. The article notes the exceptional importance of special norms in regulating the activities of peasant farms and the need to codify legislation in this area due to its specificity.
\end{abstract}

\section{Introduction}

We would like to pay special attention to the legal regulation of bankruptcy of a peasant (farmer's) economy in modern conditions of development of agro-industrial complex because it is one of the largest inter-industry complex aimed at the production and processing of agricultural raw materials and produce of products brought to the end user.

At the present stage of the development of the Russian economy, it is becoming obvious that any enterprise must skillfully adapt to the requirements of the surrounding reality in order to maintain financial stability and long-term competitiveness. Forecasting the financial insolvency of an economic entity is based on the assessment of its financial condition using such methods as anti-crisis policy, official bankruptcy, forecasting methods and criteria, as well as quantitative and qualitative models for assessing the financial condition [1].

Developing urgent measures to support small and medium-sized businesses is the only way to keep them viable. These measures should be based on a clear regulatory framework, vague interpretations and legal incidents are not allowed. Particular attention is paid to the legislative substantiation of entrepreneurship in Russia and the identification of shortcomings of the newly established regulatory legal acts. [2].

The normative legal acts, by means of which the legal regulation of relations arising in connection with the insolvency (bankruptcy) of the debtor is carried out, together constitute a system of legislation, which it is advisable to call the legislation on insolvency (bankruptcy).

* Corresponding author: oksasha morozova 2014@mail.ru 
As the history of the development of bankruptcy legislation shows, it should be recognized as ineffective, and does not correspond to the principle of unification of the legal regulation of bankruptcy.

The need for legislative regulation of the specifics of the bankruptcy of a peasant (farmer) farm is due to the specifics of the legal status of peasant (farmer) farms under Russian law, as well as the seasonal nature of agricultural work.

Modern legal regulation of insolvency (bankruptcy) is in the Federal Law N 127-FL "On Insolvency (Bankruptcy)" of 26.10.2002 [3] and the Civil Code of the Russian Federation [4] which establishes the grounds for declaring a debtor insolvent (bankrupt), defines the peasant farm. Also the procedure and conditions for implementing measures to prevent insolvency( bankruptcy), the procedure and conditions for conducting procedures applied in a bankruptcy case, and other relations of the debtor's inability to fully satisfy the claims of creditors with special features, are established by paragraph 3 of Chapter 10 of the Bankruptcy Law.

A peasant (farm) economy is a voluntary association of citizens related by kinship or property, having property in common ownership, on the basis of membership for joint production or other economic activities in the field of agriculture (production, processing, storage, transportation and sale of agricultural products), based on their personal participation and the consolidation of property contributions by members of the peasant (farm) economy, as well as the head of the peasant (farm) economy, a citizen registered as an individual entrepreneur can be [5].

Currently the legislator has defined a peasant (farmer) farm as a legal entity and a commercial corporate organization that occupies an intermediate position between economic partnerships and economic companies.

Such a novelty at the legislative level was not accompanied by the establishment of a detailed regulation of all the most important issues of the creation, operation and termination (bankruptcy) of this type of legal entity. This conclusion also applies to the grounds, procedure, conditions and consequences of the bankruptcy of this subject of the agro-industrial complex.

The insolvency (bankruptcy) of a peasant (farmer) farm is one of the grounds for the termination of the existence of a peasant (farmer) farm.

We will analyze the legal basis for the bankruptcy of the peasant (farmer) economy as one of the spheres of the agro-industrial complex of modern Russia in the article.

\section{Peculiarities of bankruptcy of peasant farms}

Large agro-industrial enterprises with their mass production are much more efficient than small peasant farms, however, farming in our country has occupied its niche in the agricultural sector especially where large enterprises are ineffective. The legal status of agricultural producers is traditionally separated into an independent regulation group. In this case a special role is assigned to peasant (farmer) households which is confirmed by the increased attention of the legislator. Agriculture is a type of entrepreneurial activity aimed at systematic profit. A peasant farm can be determined an agricultural producer in accordance with the legislation of the Russian Federation. Consequently, the main subjects of interaction in the agro-industrial complex are commercial organizations and peasant farms, the status of which is determined by part of the first Civil Code of the Russian Federation. Currently, the legislation on entrepreneurial activity is a fairly large array of normative legal norms. In this regard the problem arises of combining this array in the form of a single base of legal norms that will regulate entrepreneurial activity and entrepreneurial legal relations. A large block of issues that are important for entrepreneurial activity must 
be settled in a codified act. The existing regulations are fragmented and contain contradictions [6]. The legal regulation of peasant farms is defined in the Federal Laws "On Peasant (Farm) Economy" [5], "On State registration of legal rntities and individual entrepreneurs" [7], "On Insolvency (Bankruptcy)" [3], "On the Development of Agriculture" [8], "On the development of small and medium-sized businesses in the Russian Federation" [9], "On the protection of competition" [10], "On consumer cooperation (consumer units, their unions) in the Russian Federation" [11], "On agricultural cooperation "[12] and others.

Since the farm is one of the subjects of entrepreneurial activity, it can also terminate its activities in the event of bankruptcy on the grounds listed in paragraphs. 3 p. 1 of Art. 21 "On the peasant (farm) economy". The bankruptcy of a peasant farm has its own specific features which are in paragraph 3 of Chapter 10 of the Bankruptcy Law.

Bankruptcy problems are commonly associated with economic disasters, but can also emerge due to extraordinary economic performance The choice of a sharing rule has a significant potential effect on the economy's general equilibrium [13].

In addition, agricultural production remains one of the specifics in terms of return on investment and profit. The seasonal nature of the harvest, which ultimately determines the profitability of an agricultural enterprise, does not always allow compliance with the requirement of systematic remuneration and material incentives for workers. In agriculture, production, financial and economic results are immeasurably more dependent on weather and climatic conditions than in other sectors. Thus, there are frequent cases of financial insolvency of agricultural enterprises, which then determine the beginning of their bankruptcy procedure [14].

Due to the specifics of the activity, the bankruptcy procedure of an agricultural organization has a number of features and nuances. According to O.A. Rushitskaya this is due to the fact that "as a rule, in the procedures for financial recovery and external management of agricultural organizations provided for in the Federal Law, the solvency of organizations is not restored, and as a result they go under the hammer. In the best case, the owner changes. At worst, nobody needs the property of agricultural bankrupts. And more and more often there are empty buildings that look with reproach through the broken windows [15].

According to $\mathrm{Yu}$. V. Zinchenko, there are two main reasons for the bankruptcy of producers, which should certainly be agreed with * * internal, depending on the investment, operational and financial activities of the enterprise, low level of personnel qualification; • external, more typical for agricultural organizations, independent of the activities of the enterprise and including, among other things, natural factors. This specificity is primarily related to the use of agricultural land as the main means of production. In addition, the activities of agricultural organizations largely depend on natural and climatic conditions, are seasonal in nature, which is somehow reflected by the legislator in its regulation [16]

Insolvency (bankruptcy) is a debtor's inability to fully satisfy creditors' claims for monetary obligations, for payment of severance pay and (or) for remuneration of persons who work or worked under an employment contract, recognized by an arbitration court or resulting from the completion of an extrajudicial bankruptcy procedure, and (or) fulfill the obligation to pay mandatory payments. The debtor in our case is a peasant farm and the basis for declaring a peasant farm bankrupt is its inability to satisfy creditors' claims for monetary obligations, inability to pay severance pay and (or) remuneration of labor of persons working or worked under an employment contract, and (or) to fulfill the obligation under payment of mandatory payments within the term. The insolvency period must be at least three months since they should have been executed for a peasant farm to be declared 
bankrupt. The Bankruptcy Law states that it is the farm that is declared bankrupt, and not its head registered as an individual entrepreneur. The head of the farm by mutual agreement of the members of the farm is one of its members. If a farm is created by one citizen then he is the head of the farm. The head of the farm must act in the interests of the farm he represents in good faith and reasonably and has no right to take actions that infringe on the rights and legitimate interests of the farm and its members [3]. If a peasant (farm) farm includes several persons (members of the farm), then an application for declaring this farm bankrupt can be filed with the arbitration court by its head - an individual entrepreneur with the written consent of all members of the peasant (farm) farm, since collection of the farm's debts is on all property of a peasant (farm) economy. It is no coincidence that a petition by the head of a farm to declare him bankrupt can be filed with an arbitration court only with the written consent of all members of the farm. The peculiarity of kinship relations is not associated with the unity of the property basis in the organization of the economy. A large number of disputes considered by the courts in case of bankruptcy of a peasant farm are related to the exclusion of the personal property of a member of the farm or its head from the common property of the farm. The duality of legal status, simultaneous membership in a peasant (farm) economy and the receipt of income as an individual who is not endowed with the status of an individual entrepreneur, indicates the problem of differentiating property and income as common means of the economy and qualifying other incomes as personal. The bankruptcy petition must contain documented information on the composition and value of the property of the peasant (farm) economy and the composition and value of property owned by the members of this farm, as well as on the sources from which it was acquired. According to paragraph 3 of Art. 221 of the Bankruptcy Law in the event that a farm is declared bankrupt and bankruptcy proceedings are opened, property owned by members of the farm, as well as other property in respect of which it has been proven that it was acquired with income that is not the common funds of the peasant (farm) farm, in bankruptcy mass is not included. The latter is formed only by the property in common ownership of the members of the peasant (farm) economy, including property rights [3].

The application is accompanied by documents confirming:

- the presence of debt, as well as the inability of the debtor to satisfy the claims of creditors in full;

- the reason for the debt;

- other circumstances on which the debtor's statement is based.

The debtor's application is also accompanied by:

- document on state registration of an individual entrepreneur;

- a list of the applicant's creditors and debtors with a breakdown of accounts payable and receivable and an indication of the addresses of the applicant's creditors and debtors;

- balance sheet as of the last reporting date or documents replacing it;

- the decision of the debtor's participants as well as another authorized body of the debtor on the debtor's appeal to the arbitration court with the debtor's application if such a decision is available;

- the decision of the debtor's participants, as well as another authorized body of the debtor on the election or appointment of a representative of the debtor's participants;

- minutes of the meeting of the debtor's employees, at which a representative of the debtor's employees was elected to participate in the arbitration process in the bankruptcy case if the said meeting was held before the debtor's application was filed; 
- a report on the value of the debtor's property prepared by an appraiser, if such a report is available;

- on the composition and value of the property of the farm;

- the composition and value of the property owned by the members of the peasant farm on the basis of the right of ownership as well as the sources at the expense of which the said property was acquired;

- the amount of income that can be received by peasant farms at the end of the corresponding period of agricultural work.

These documents are also attached by an individual entrepreneur - the head of a peasant (farm) economy to the response to the creditor's application. The state registration of the head of the peasant (farm) economy as an individual entrepreneur becomes invalid since the moment the decision is made to declare the peasant (farm) economy bankrupt and bankruptcy proceedings are opened.

\section{Bankruptcy procedures of a peasant (farm) economy}

The folloing bankruptcy procedures are applied to a peasant (farm) economy according to the Bankruptcy Law [3]:

Table 1. Bankruptcy procedures of a peasant (farm) economy.

\begin{tabular}{|c|c|}
\hline Observation & $\begin{array}{l}\text { Introduced following the results of the } \\
\text { consideration by the arbitration court of the validity } \\
\text { of the application for declaring the debtor bankrupt, } \\
\text { it is not a reason for the removal of the head of the } \\
\text { debtor and other management bodies of the debtor, } \\
\text { which continue to exercise their powers with } \\
\text { restrictions }\end{array}$ \\
\hline Financial recovery & $\begin{array}{l}\text { Introduced by the arbitration court on the basis of } \\
\text { the decision of the meeting of creditors, introduced } \\
\text { for a period not exceeding two years. }\end{array}$ \\
\hline External management & $\begin{array}{l}\text { Introduced by the commercial court on the basis of } \\
\text { a decision of the creditors ' meeting, introduced for } \\
\text { a period of no more than eighteen months, which } \\
\text { can be extended. }\end{array}$ \\
\hline Bankruptcy proceedings & $\begin{array}{l}\text { The adoption by the arbitration court of a decision } \\
\text { on declaring the debtor bankrupt is introduced for a } \\
\text { period of up to six months. The period of } \\
\text { bankruptcy proceedings may be extended at the } \\
\text { request of the person participating in the case for no } \\
\text { more than six months. }\end{array}$ \\
\hline Settlement agreement & $\begin{array}{l}\text { At any stage of the bankruptcy case consideration } \\
\text { by the arbitration court, the debtor, his bankruptcy } \\
\text { creditors and authorized bodies have the right to } \\
\text { conclude an amicable agreement. Adopted by a } \\
\text { majority of votes of the total number of votes of } \\
\text { bankruptcy creditors }\end{array}$ \\
\hline
\end{tabular}

Most of the listed procedures have a certain specificity due to the fact that the peasant (farm) economy carries out agricultural production associated with the seasonality of work 
and great dependence on natural conditions, respectively the possibility of restoring its solvency is not excluded. The head of the peasant (farm) farm within two months since the arbitration court's ruling on the introduction of supervision over the peasant farm submits to the arbitration court a financial recovery plan and a debt repayment schedule. If the implementation of the measures stipulated by the financial recovery plan will allow the peasant farms, including from the income that can be received by the peasant farms at the end of the corresponding period of agricultural work, to pay off the claims of creditors for monetary obligations and for the payment of mandatory payments in accordance with the debt repayment schedule, the arbitration court introduces the financial recovery of the farm. The arbitration court issues a ruling on the introduction of financial rehabilitation of peasant farms, which can be appealed. Financial rehabilitation of peasant farms is introduced before the end of the corresponding period of agricultural work, taking into account the time required to sell the produced (or produced and processed) agricultural products. If during the financial recovery there was a recession and deterioration in the financial condition of peasant farms due to natural disasters, epizootics or other circumstances of an emergency nature, the period of financial recovery may be extended by a year, subject to changes in the debt repayment schedule.

The arbitration court introduces external management on the basis of the decision of the meeting of creditors if there is a possibility of restoring the solvency of the farm. External management of peasant farms is introduced before the end of the corresponding period of agricultural work, taking into account the time required to sell the produced (or produced and processed) agricultural products. As a general rule, the aggregate period of financial rehabilitation and external management cannot exceed two years. In the case of peasant farms, the term of external management cannot exceed this term by more than three months. If in the course of external management there was a recession and deterioration in the financial condition of peasant farms due to natural disasters, epizootics and other circumstances of an emergency nature, the term of external management may be extended by a year. External management of a peasant (farm) economy may be terminated ahead of schedule by an arbitration court on the basis of an application by an external manager or any of the creditors in the event of:

- non-fulfillment of measures provided for by the external management plan;

- presence of other circumstances indicating the impossibility of restoring the solvency of the peasant (farm) economy.

The early termination of external management of the peasant (farm) economy entails its recognition as bankrupt and the opening of bankruptcy proceedings. To conduct external management of a peasant farm, an external manager is approved by the arbitration court. I would like to note that an external manager can be approved by a person who does not meet the requirements of the Bankruptcy Law for bankruptcy managers and the powers of an external manager can be transferred to the head of a farm with the consent of the external manager. In the event that a peasant (farm) economy is declared insolvent (bankrupt) and bankruptcy proceedings are opened, persons engaged in the production of agricultural products and owning land plots directly adjacent to the land plot belonging to the peasant (farm) farm have the preferential right to acquire the property of the peasant (farm) farm with public auction. When selling the property of a debtor - a peasant farm, the arbitration manager must put up for sale the debtor's enterprise - a peasant farm by holding an auction, and for this he needs to determine the bankruptcy estate. The bankruptcy estate of peasant farms includes real estate in common ownership of peasant farm members, including plantings, household and other buildings, reclamation and other structures, breeding, dairy and draft cattle, poultry, agricultural and other machinery and equipment, vehicles, 
inventory and other property acquired for a PF using the common funds of its members, as well as the right to lease a land plot belonging to a PF and other property rights owned by a $\mathrm{PF}$ and having a monetary value. In the event of bankruptcy of a peasant farm, the land plot belonging to it may be alienated or transferred to another person, the Russian Federation, a constituent entity of the Russian Federation or a municipal entity, to the extent that its turnover is permitted by land legislation.

Property is not included in the bankruptcy estate owned by the head of a peasant farm and members of peasant farms by right of ownership, as well as other property in respect of which it is proven that it was acquired with income that is not the common funds of peasant farms is not included in the bankruptcy estate. If the debtor's enterprise - a peasant farm was not sold at the auction, the arbitration manager puts up for auction in a single lot the property of the debtor - a peasant farm, which is used for the production of agricultural products, its storage, processing and sale. The sale of peasant farms and the industrial and technological complex put up for auction in a single lot is carried out in accordance with the procedure established by clauses 4-10 of article 110 of the Bankruptcy Law. Assessment of the property of a farm with the involvement of a professional appraiser is carried out on the basis of Article 130 of the Bankruptcy Law [2]. Persons engaged in the production of agricultural products and owning land plots directly adjacent to the land plot owned by the PF have the preferential right to acquire the property of peasant farms. To ensure the implementation of the preemptive right to acquire the debtor's property, the arbitration manager sends a notice of the sale of property to persons who are engaged in the production of agricultural products and own a land plot immediately adjacent to the debtor's land plot, and also publishes information on the sale of the debtor's property in the press at the debtor's location with an indication of the initial sale price of the debtor's property put up for auction. If the specified persons, within a month from the date of receipt of the proposal for the acquisition of property and property rights, did not declare their desire to acquire property and rights of claim, the arbitration manager or the head of the peasant (farm) economy shall realize the property and property rights. Subsequently, the Arbitration Court sends a copy of the decision on declaring the peasant (farm) farm bankrupt and on the opening of bankruptcy proceedings to the authority that registered the head of the peasant (farm) farm as an individual entrepreneur.

\section{Problems of bankruptcy of a peasant (farm) economy}

The legal structure of bankruptcy allows for the existence of three types of peasant (farm) economy: in the form of an individual entrepreneur who is the head of the farm and acts alone; in the form of a contractual association of members of a given farm; in the form of a commercial corporate legal entity. Despite the fact that the rules on bankruptcy of a peasant (farm) economy are located in the chapter on bankruptcy of citizens, however, the principles and basic algorithms for bankruptcy of citizens do not apply to the sphere of insolvency (bankruptcy) of a peasant (farm) farm. The legal nature of the insolvency (bankruptcy) of a peasant (farm) economy is similar to the legal nature of the commercial bankruptcy of legal entities and does not apply to mechanisms affecting the interests of the consumer. The institution of insolvency (bankruptcy) of a peasant (farm) economy is as close as possible to the bankruptcy of business entities, although it has certain features arising from the specifics of the legal regime of property of these types of farms and their type of activity. Consequently, the bankruptcy of a peasant (farm) economy, being one of the elements of the institution of insolvency (bankruptcy) of citizens, cannot be 
substantively attributed to consumer bankruptcy. In this regard, the question of including this section in the chapter on the bankruptcy of citizens is highly controversial. A significant number of farms are being liquidated on general grounds provided for by law.

The application of liquidation procedures for insolvency (bankruptcy) in relation to these entities cannot be considered as market rehabilitation, since in reality it causes negative socio-economic consequences. The institution of bankruptcy is ineffective due to the considerable duration and high cost, different interests of the participants in insolvency cases. The creditor does not have an unconditional right to receive from the manager financial and other documents on the composition of the debtor's property or his transactions. Therefore, if the manager is unscrupulous the creditor often does not even know how to "approach" the task of returning assets to the bankruptcy estate that were sold for next to nothing. Bankruptcy law has a significant bias towards protecting the rights of creditors. Debtors have practically no opportunity to cope with their entrepreneurial risks in a civilized manner. Judicial practice mainly meets the interests of debtors, whose main task is to write off debts and be excluded from the register.

There is no doubt that there is not even a full-fledged qualitative commentary on the bankruptcy law. Also, of course, bankruptcy is experiencing all the systemic problems of our society - including the total distrust of everyone in each other. The bankruptcy law is defined for the insolvency of an individual, although almost all large and medium-sized businesses, which include the agro-industrial complex, and as one of its elements is a peasant (farm) economy - these are holding structures in the hands of common beneficiaries. They can collect assets in one company and debt in another. This, on the one hand, complicates the actual collection through bankruptcy, and on the other hand, it makes it easier for debtors to withdraw assets and gain control over bankruptcy. The main reasons for bankruptcy during a pandemic, first of all, include the inability to fulfill their debt obligations on bank loans. A significant part of small and medium-sized businesses in Russia is extremely indebted, and the reduction or even complete cessation of income during the period of restrictive measures led to the impossibility of making loan payments. Despite such a measure as the introduction of credit holidays, many entrepreneurs were still forced to pay on loans, and they could not fulfill their loan obligations. Inability to fulfill obligations to pay utility bills, wages and insurance premiums. Of course, at first glance, the problem of paying wages can be solved by reducing the number of employees. However, since dismissal on staff reduction requires the payment of severance pay, according to Art. 180 of the Labor Code [17], this decision is also not decisive for some small businesses.

According to V.N. Tkachev, the Bankruptcy Law should be supplemented with a norm on the need to take into account the financial and economic activities of the debtor not only during the last year preceding the date of the relevant procedure, but also the average indicator for the entire period of existence of the debtor. Moreover, the choice of the settlement procedure should be givento the debtor himself, which will better protect the interests of the agricultural debtor [18].

Over the 19 years of the existence of the Bankruptcy Law, everything has changed fundamentally: business, life, trends, the economy. The law, however, remains the same, not responding to the movement of the market. The situation has worsened due to the forced self-isolation and the virtual stop of business life around the world. The current bankruptcy legislation is in urgent need of revision. It is necessary to focus not on satisfying the interests of creditors, but on the financial recovery of debtors, the preservation of which will subsequently make a significant contribution to the country's economy. 
The active use of the institution of bankruptcy will not lead to solving the problems facing the state of developing the domestic food market. Considering the significant number of farms that voluntarily terminate their activities most often due to negative results of their activities. It is required to stimulate the growth of production of basic types of agricultural products, improve the quality of life of the rural population to ensure food independence of Russia, increase the competitiveness of Russian agricultural products, increase the financial stability of enterprises in the agro-industrial complex.

In modern economic conditions, the main goal of managing an organization is to provide an effective management model, the main characteristic of which is the construction of a strategy for the development of an organization that will ensure the achievement of the indicators specified in it, the production efficiency of the resources used, financial stability, competitiveness and effective management of the organization's personnel. One of the main elements of building this system is the timely identification of existing risks that directly affect the assessment of the likelihood of insolvency (bankruptcy) of the organization [19].

Despite the fact that conditions have been created for the sustainable development of agricultural production based on increasing its competitiveness, it is necessary to continue, the formation of a comprehensive economic and legal policy to support domestic producers in the field of agriculture.

As noted, Bazenov, A.B., Begzhan, A.M., Zhunissov, Z.S., Tazhikov, A.K., Amandossuly «the transitional stage in the agrarian economy requires an optimal combination of state protection and market levers. At present, the state regulatory influence on the development of the agricultural economy remains, on the one hand, quite significant, and on the other, insufficiently effective. There is no systemic integrity in the practice of state regulation of the agricultural sector» [20].

\section{Conclusion}

We would like to note that the legal status of the peasant (farm) economy has changed significantly during all the reforms of civil legislation. The legislator recognized the possibility of creating a peasant (farm) economy as a legal entity (along with peasant (farm) farms that do not have the status of a legal entity). The legislator has defined a peasant (farming) enterprise, which is a legal entity, as a commercial corporate organization that occupies an intermediate position between economic partnerships and business entities. Unfortunately, such a radical legislative novelty was not accompanied by the establishment of detailed regulation of almost all the most important issues of the creation, operation and termination of a new type of legal entity. This conclusion fully applies to the grounds, procedure, conditions and consequences of the reorganization of this type of legal entity.

It is necessary to pay attention to the application of liquidation procedures of insolvency (bankruptcy) in relation to the peasant (farm) economy, it cannot be considered as a reorganization of the market since in reality it causes negative socio-economic consequences. Considering the significant number of farms that voluntarily terminate their activities, most often due to negative results of their activities, the active use of the institution of bankruptcy will not lead to solving the problems facing the state of developing the domestic food market.

It is necessary to improve the legislation on the financial recovery of agricultural producers and actively use it in practice. The most effective a working with insolvent farms. The goal of the financial rehabilitation of agricultural producers is to establish 
conditions for restructuring the debts of agricultural producers in order to improve their financial condition before the application of bankruptcy procedures, i.e. help to maintain the property and social status of the debtor with the restructuring of loan payments.

It should be noted that there is a clear contradiction in Russian legislation regarding the legal status of business entities. Regardless of whether the farm is a legal entity or a form of individual entrepreneurial activity, the scope of its responsibility is overstated in comparison with economic societies or cooperatives. The social significance and risky nature of the activities of agricultural producers are incommensurate with the responsibility of participants in other legal entities. To impose subsidiary (additional) liability on them with other property means a demonstration of a deliberate distrust of the public authorities to the rural worker and entrepreneur, who, in the event of a crop failure, will already incur losses, and with subsidiary liability, the amount of these losses will be greater.

For the development of farms and the restoration of the solvency of those of them who fall under the signs of insolvency (bankruptcy), it is necessary to expand the powers of arbitration managers in actions aimed at preserving the assets of the farm.

Preserving the potential of entrepreneurial activity among citizens living in rural areas will allow an objective assessment of the effectiveness of subsidies and other support measures issued by the state. It is required to stimulate the growth of production of basic types of agricultural products, improve the quality of life of the rural population to ensure food independence of Russia, increase the competitiveness of Russian agricultural products, increase the financial stability of agricultural enterprises, state support at the federal and regional level in the form of grants for novice farmers, interest rate reimbursement for longterm and short-term loans. As the monitoring of the official websites of regional departments and the website of the Ministry of Agriculture of Russia shows, the leading tool in solving these problems is a "grant for the development of a family farm" - budgetary allocations transferred from the budget of the constituent entity of the Russian Federation and (or) the local budget in accordance with the decision of the regional competition commission to the head of the peasant (farm) economy to co-finance his costs that are not reimbursed within the framework of other areas of support in accordance with the state program of the constituent entity of the Russian Federation (subprogram) and (or) the municipal program, in order to develop a peasant (farm) ) farms and the creation of new permanent jobs in rural areas based on the calculation of the creation of at least 3 new permanent jobs per 1 grant within the period determined by the subject of the Russian Federation, but not later than the term of the grant.

At the same time, the grant funds for the development of a family farm can be spent on small businesses, the provision of state support to family farms, subsidies, the organization of competitions with the allocation of significant funding for the winners.

Based on this, it can be concluded that the government could adopt a strategy to support farmers by providing financial support to increase working capital and reduce costs, and the results of the support will be useful for politicians, farmers and processors [21]

Legal regulation of the agro-industrial complex is carried out within the framework of a comprehensive state policy by authorized state authorities endowed with general and special competences. In the Russian Federation, this regulation is implemented at the federal and the level of the constituent entities of the Russian Federation, specialized state management and control bodies, as well as local self-government bodies. At the national level the powers in the scope of sectoral and specialized regulation function while at the territorial level the agro-industrial complex is regulated by territorial executive bodies and in the scope of powers of local self-government bodies. 
At the modern level, the types of support for the agro-industrial complex are becoming relevant, because are aimed at increasing the purchasing power of farmers by investing in the production of high value-added products using competitive technologies and long-term strengthening of their position in the dynamically changing world markets [22]

In this regard, special attention should be paid to measures to support and protect domestic producers in those regions where the economic conditions have a certain specificity.

\section{References}

1. O.S Aksinina, Lecture Notes in Networks and Systems, 160 (LN), 510-519 (2021)

2. A.V. Fadeev, Lecture Notes in Networks and Systems, 139, 275-282 (2021)

3. Federal Law of October 26, 2002 No. 127-FZ "On Insolvency (Bankruptcy)" (as amended on December 30, 2020)

4. Civil Code of the Russian Federation (part one) of 30.11.1994 No. 51 - FZ (as amended on 08.12.2020)

5. Federal Law "On Peasant (Farming) Economy" dated 11.06.2003 No. 74-FL (as amended on 29.12.2020)

6. O. A. Morozova, International scientific periodical "Modern fundamental and applied researches", 2 (2-21), 145-150 (2016)

7. Federal Law "On State Registration of Legal Entities and Individual Entrepreneurs" dated 08.08.2001. No. 129-FL (as amended on July 31, 2020)

8. Federal Law of December 29, 2006 No. 264-FL "On the Development of Agriculture" (as amended on October 15, 2020)

9. Federal Law "On the Development of Small and Medium-Sized Businesses in the Russian Federation" dated 24.07.2007 No 209 - FL (as amended on 01.01.2021)

10. Federal Law "On Protection of Competition" dated 26.07. 2006 No. 135 - FL (as amended on 22.12.2020)

11. Federal Law "On consumer cooperation (consumer societies, their unions) in the Russian Federation" dated 23.04.2012 No. 37 - FL (as amended on 02.07.2013)

12. Federal Law "On Agricultural cooperation" dated 08.12.1995 N 193-FL (as amended on 08.12.2020)

13. I. Lipschütz, M.E. Schwarz, Review of Law and Economics, 16 (3), $45-57$ (2020)

14. E.A. Letyagina, E.V. Dadayan, A.N. Storozheva, IOP Conference Series: Earth and Environmental Science, 548 (2), 022002 (2020)

15. O. A. Ruschitskaya, Agrarian Bulletin of the Urals, 8(126), 102 (2014)

16. Y. Zinchenko, L. Orekhova, Young researcher of the Don, 1 (4), 112 (2017)

17. Labor Code of the Russian Federation of December 31, 2001, No. 197-FL(as amended on December 29, 2020)

18. V. N. Tkachev, Insolvency (bankruptcy) of special categories of subjects of competition law: theoretical and practical problems of legal regulation, Moscow: Voltersklover (2007)

19. E. Sivolapenko, O.Tyutyunik, E35 Web of Conferences, 210, 13008 (2020)

20. A.B. Bazenov, A.M. Begzhan, Z.S. Zhunissov, et al., International Journal of Criminology and Sociology, 9, 3175-3186 (2020) 
21. M. Uddin, A.Akter, A. Khaleduzzaman, et al., Tropical Animal Health and Production, 53 (1), 33 (2021)

22. G.P. Gagarinskaya, A.V. Gagarinskii, E.S. Potokina, T.N. Obuschenko, Lecture Notes in Networks and Systems, 139, 201-211 (2021) 